This item was submitted to Loughborough's Research Repository by the author.

Items in Figshare are protected by copyright, with all rights reserved, unless otherwise indicated.

\title{
Birth weight, birth order, and age at first solid food introduction influence child growth and body composition in 6 to 8-year-old Maya children: the importance of the first 1000 days of life.
}

\section{PLEASE CITE THE PUBLISHED VERSION}

https://doi.org/10.1002/ajhb.23385

\section{PUBLISHER}

Wiley

\section{VERSION}

AM (Accepted Manuscript)

\section{PUBLISHER STATEMENT}

This is the peer reviewed version of the following article: SANCHEZ-ESCOBEDO, S. ... et al, 2020. Birth weight, birth order, and age at first solid food introduction influence child growth and body composition in 6- to 8-year-old Maya children: The importance of the first 1000 days of life. American Journal of Human Biology, 32 (5), e23385, which has been published in final form at https://doi.org/10.1002/ajhb.23385. This article may be used for non-commercial purposes in accordance with Wiley Terms and Conditions for Use of Self-Archived Versions

\section{LICENCE}

CC BY-NC-ND 4.0

\section{REPOSITORY RECORD}

Sanchez-Escobedo, Samantha, Hugo Azcorra, Barry Bogin, Almira Hoogesteyn, Reyna Sámano, Ines VarelaSilva, and Federico Dickinson. 2020. "Birth Weight, Birth Order, and Age at First Solid Food Introduction Influence Child Growth and Body Composition in 6 to 8-year-old Maya Children: The Importance of the First 1000 Days of Life.". Loughborough University. https://hdl.handle.net/2134/11876961.v1. 


\section{American Journal of Human Biology}

WILEY

Birth weight, birth order, and age at first food introduction influence child growth and body composition in 6 to 8-yearold Maya children: the importance of the first 1000 days of life

\begin{tabular}{|c|c|}
\hline Journal: & American Journal of Human Biology \\
\hline Manuscript ID & AJHB-18-0245.R3 \\
\hline Wiley - Manuscript type: & Original Research Article \\
\hline $\begin{array}{r}\text { Date Submitted by the } \\
\text { Author: }\end{array}$ & 16-Dec-2019 \\
\hline Complete List of Authors: & $\begin{array}{l}\text { Sanchez-Escobedo, Samantha; Centro de Investigacion y de Estudios } \\
\text { Avanzados Unidad Merida, Ecología Humana } \\
\text { Azcorra, Hugo; Centro de Investigación y de Estudios Avanzados del } \\
\text { Instituto Politecnico Nacional, Departamento de Ecología Humana } \\
\text { Bogin, Barry; Loughborough University, School of Sport, Exercise \& } \\
\text { Health Sciences } \\
\text { Hoogesteyn, Almira; Centro de Investigacion y de Estudios Avanzados } \\
\text { Unidad Merida, Ecología Humana } \\
\text { Sámano, Reyna; Instituto Nacional de Perinatologia, Nutrición y } \\
\text { Bioprogramación } \\
\text { Varela-Silva, Maria; Loughborough University, Human Sciences } \\
\text { DICKINSON, FEDERICO; Centro de Investigación y de Estudios } \\
\text { Avanzados, Departamento de Ecología Humana }\end{array}$ \\
\hline Keywords: & $\begin{array}{l}\text { Child growth, Body composition, Environmental factors, First } 1000 \text { days } \\
\text { of life, Maya Children }\end{array}$ \\
\hline
\end{tabular}

\section{SCHOLARONE Manuscripts}


Birth weight, birth order, and age at first solid food introduction influence child growth and body composition in 6 to 8-year-old Maya children: the importance of the first 1000 days of life.

Samantha Sanchez-Escobedo ${ }^{1,6 \S}$, Hugo Azcorra ${ }^{5}$, Barry Bogin²,3, Almira L. Hoogesteijn ${ }^{1}$, Reyna Sámano ${ }^{4}$, Maria Ines Varela-Silva², Federico Dickinson¹.

\section{1: Departamento de Ecología Humana}

Centro de Investigación y de Estudios Avanzados del Instituto Politécnico Nacional

Mérida, Yucatán, México

Antigua carretera a Progreso Km 6, C.P. 97310

2: Loughborough University, School of Sport, Exercise and Health Sciences

United Kingdom LE11 3TU

3: UCSD/Salk Center for Academic Research and Training in Anthropogeny (CARTA), USA

4: Departamento de Nutrición y Bioprogramación

Instituto Nacional de Perinatología

Montes Urales 800, Colonia Lomas de Virreyes, 11000 Miguel Hidalgo, Ciudad de México, México.

5:Current address: Centro de Investigaciones Silvio Zavala, Universidad Modelo

Carretera a Cholul 200 mts periferico norte, Mérida, Yucatán, México.

6: Universidad Vizcaya de las Américas.

Calle 33 \#140 Entre calle 20 A y 22 Col, Chuburná de Hidalgo, 97205 Mérida, Yuc.

$\S$ : corresponding author 


\begin{abstract}
Objectives: To analyze the relationship of birth weight, birth order, breastfeeding duration, and age of introduction of solid foods with height, fat mass, and fat-free mass in a sample of Maya children when aged 6 to 8 years old.
\end{abstract}

Methods: We collected data on anthropometry, body composition, children's birth weight, birth order, early feeding practices, and household socioeconomic characteristics in a sample of 260 Maya children aged 6 to 8 years living in Merida and Motul, two cities in Yucatan, Mexico. Multiple regression models were performed to identify variables associated with height-for-age (HAZ), fat mass index (FMI) and fat-free mass index (FFMI). The predictors included in the models were: birth weight $(\mathrm{kg})$, birth order, duration of breastfeeding (months), age at introduction of solid foods (months), maternal age (years) and height (cm). Models were adjusted for the influence of children's age and sex, maternal educational level, and household overcrowding.

Results: HAZ was positively associated with child birthweight and maternal height and age, but inversely associated with birth order and age of introduction of solid foods. FMI was positively associated with birth weight, maternal age, and height, and negatively associated with birth order. FFMI was positively associated with maternal age and birth weight.

Conclusions: These results are evidence of the importance of the first 1000 days of life for the growth and body composition of Maya children and contributed to understand the development of nutritional dual burden in this population.

Key words: Child growth; Body composition; Environmental factors; First 1000 days of life, Maya Children 


\section{INTRODUCTION}

Both national and regional studies have reported high rates of stunting and overweight/obesity (OW/OB) among the population of the Yucatan Peninsula, Mexico (Azcorra et al., 2010; Dickinson Bannack, 1997; Mendez et al., 2016). This phenomenon, known as dual-burden of malnutrition, is particularly noteworthy among the Yucatec Maya (Azcorra et al., 2013), which represent $44 \%$ of the population of the state of Yucatan (INEGI, 2010).

Ethnic Maya populations have been living for centuries in Mexico, Guatemala, and Belize, both in urban and rural contexts (Bogin et al., 2014). All of them have experienced social and economic oppression that began with the first European contacts in the $16^{\text {th }}$ Century and still is present nowadays. Overall, this oppression, historical racism, and systemic segregation has translated into more than five centuries of negative living conditions for the Maya (Bracamonte, 2007). The Maya people of today experience disadvantageous socioeconomic conditions compared to the rest of population, but are well-integrated into global economic processes in terms of state education, employment, and consumption of foods and national material culture (Bogin et al. 2014).

This biocultural history produced a phenotype that was characterized by impaired linear growth status and thinness in Maya children. Beginning in the 1980s the short-thin phenotype began to change into one of short stature with high levels of body adiposity. This double-burden of malnutrition is associated with the current-day high prevalence of adult obesity, type 2 diabetes mellitus, hypertension and other metabolic disorders (Azcorra et al., 2015a; Varela-Silva et al., 2009; Varela-Silva et al., 2012). The change from thinness to fatness of Maya people is associated with nutrition and demographic transitions (Bogin et al., 2014). Our previous research reported that intergenerational effects contribute to perpetuating health problems in this population (Azcorra et al., 2015a; Azcorra et al., 2015b; Azcorra et al., 2013; Varela-Silva et al., 2009). A question remains as to when during the life cycle (fetus, infant, child, adolescent, pregnant woman) the growth of the Maya is most sensative to these environmental influences. 
Physical growth is a complex biological process involving multiple factors during different life stages and their effects are cumulative. This means that the growth status of an individual, at any given moment, is the result of the individual's health and nutrition history (Bogin, 2001; Himes, 2004; Stinson, 2012). A particularly critical life stage impacting human health is first 1000 days of life from conception. This 1000 days includes 270 days of prenatal development + 365 days of first postnatal year +365 days of second postnatal year. Poor environmental conditions during this period are associated with unhealthy patterns of growth and development in later life and with higher morbidity and mortality rates in adulthood (Chandler-Laney et al., 2013; Gluckman et al., 2008; Hanson and Gluckman, 2014; Kulkarni et al., 2014; Kuzawa, 2005; Martorell and Zongrone, 2012; Sayers et al., 2009; Wells, 2013; Wells, 2009; Wells, 2014).

Growth retardation in the first 1000 days is associated with poor maternal nutritional history, inadequate nutrition to fetus and infant, infectious disease, and inadequate psychosocial stimulation (Stinson, 2012; WHO, 2014). Birth weight is a measure of total intrauterine body growth. Variation in birth weight may be influenced by many factors, and some of these are associated with maternal nutritional history and nutritional and environmental circumstances experienced during gestation (Schell, 1998; Himes, 2004). Breastfeeding overall, and its duration, influence growth because certain nutrients and immune factors are present only in human milk and allow optimal expression of growth (Colen and Ramey, 2014). Breastfeeding also supports intimate mother-infant contact that enhances positive psychosocial and emotional stimulation. Duration of breastfeeding and the age of introduction of solid foods are two interrelated variables that influence nutritional and emotional status during the first 1000 days. According to the World Health Organization (WHO), babies should be exclusively breastfed from birth to 6 months of postnatal life and then begin the transition from maternal milk as the main food to solid foods (OMS, 2015). Breastfeeding and age of introduction of solid foods are modifiable factors, influenced by public health policies, maternal perceptions regarding the importance of breastfeeding, as well as the amount and quality of resources mothers have to be able to properly breatfeed their infant. Early or late solid 
food introduction (<4.0 months or $>6.9$ months) may be linked to conditions such as growth retardation and/or increased adipose tissue accumulation later in life (Kuo et al., 2011).

The purpose of this paper was to analyze the relationship of birth weight, birth order, breastfeeding duration, and age of introduction of solid foods (independent variables) with height, fat mass and fat-free mass (dependent variables) in a sample of Maya children when aged 6 to 8 years old. This age range represents the late childhood and early juvenile phase of growth, a phase of relatively slow growth when the intergenerational and early life influences on body size and composition are established (Bogin, 1999; Bogin and MacVean 1981). We test the overall hypothesis that the first 1000 days of life are a critical period in terms of linear growth and body composition. Our specific hypothesis is that greater birthweight, lower birth order, and greater adherence to WHO recommendations regarding breastfeeding and the introduction of solid foods reduce the risk for the development of the dual burden of malnutrition among the Maya.

\section{METHODS}

\section{The study location}

We conducted a cross-sectional and retrospective study in two cities in the state of Yucatan, Mexico: 1) Merida, the state capital (population 777,615); and 2) Motul, a smaller city (population 23,240) 45 kilometers northeast of Mérida. In both places there is a numerically and socially important Maya population. In the case of Mérida, its Maya presence is explained by a rural-to-urban migratory process that began at the start of the twentieth century with the decline of the sisal agroindustry (a plant crop used for its fiber) and the eventual collapse of that agroindustry in the second half of this century. The Maya presence in Motul is due to it being a founded in the 11th century AD by a Maya priest named Zac Mutul. Sometime after the year 1440 Motul became the capital of a regional Maya kingdom called Cehpech. The Spanish Conquistador Francisco de Montejo founded Motul as Spanish colonial town by the middle of 16 th century (H. Ayuntamiento de Motul). 


\section{Sample}

The recruitment process was conducted in the primary schools and only targeted our population of interest - the Maya. The Maya have characteristic surnames that are, generally, distinct from Mestizo and other non-Maya ethnic groups. Following the surname methodology of Relethford (1995) we used Maya surnames as a proxy of ethnic ancestry to select the participants for our study. We included all children meeting the inclusion criteria, which were: (i) aged 6.008.99y and (ii) maternal Maya surname. In the case of Merida we focused recruitment on areas of the city with relatively high numbers of Maya population, based on census data from the National Institute of Geography and Statistics. The final sample consisted of 260 children (128 girls); 180 residing in Merida and 80 in Motul. In Merida, participants were recruited from 47 schools in low-income neighborhoods, with a high concentration of Maya speakers, located in several areas of the city. To allow for maximum socioeconomic variability in the sample, we selected no more than 10 children from each school. In schools where more than 10 children met the inclusion criteria, 10 were randomly selected. In the case of Motul, mother-child dyads were recruited in all public primary schools of the city $(n=12)$.

\section{Data collection}

The fieldwork took place between 2011-2014 in Merida, and 2014-2015 in Motul. Identical data collection methods were used in both locations. The children were measured at school, in the morning, before the recess and two hours after food consumption. Anthropometric measures collected were height $(\mathrm{cm})$, weight $(\mathrm{kg})$, waist circumference $(\mathrm{cm})$ and subscapular skinfolds $(\mathrm{mm})$ following the Anthropometric Standardization Reference Manual (Lohman et al., 1988). We used a Martin anthropometer, a SECA scale, a SECA measuring tape, and a Harpenden skinfold caliper. Anthropometric data collected were then converted into z-scores against the Comprehensive Reference Data published by Frisancho (2008), which were based on the United States NHANES III survey. The cut-off points to define nutritional status variables were: stunting $<5$ th percentile of height-for-age; OW/OB $>85$ th percentile of body mass index (BMI) for-Age; excessive centralized fat $>85$ th percentile of waist circumference-for-age; excessive trunk fat $>85$ th percentile subscapular 
skinfold-for-age. We estimated body composition from bio-electric impedance analysis using a Bodystat 1500 Monitoring Unit (Bodystat LTD). The Body Composition Monitoring Unit passes a very low current $(50 \mathrm{HZ})$ through the body tissues. Each body tissue has a different resistance. To estimate fat-free mass (FFM) we used the resistance value, plus the height and weight, with the prediction equation developed by Ramirez et al. (2012). This equation is based on a sample of Mexican school children from different geographical regions and ethnicities within the country. Then fat mas (FM) was indirectly calculated (FM = body weight [kg] - FFM [kg]). Finally, we converted the absolute values of FFM and FM into indices using the formula of Frisancho (2008). Each index is calculated by dividing the FFM or the FM, in kilograms, by height in metres squared.

Children's mothers were visited at their houses and interviewed to obtain biologic and socioeconomic data. Children's birth weight was obtained from birth certificates. We asked the mother to tell us the names and ages of all their children, so we could calculate the birth order of the studied child. This variable was then categorized as: 1 = first born, 2 = second born, 3 = third or later born. Mother's height was obtained by anthropometry during home visits. We used a questionnaire designed by the research staff of the Somatology Laboratory at Cinvestav-Mérida to collect information on breastfeeding duration, first solid food introduction, and maternal educational level (years of formal education). Maternal age at childbirth was estimated by subtracting the child's age from current maternal age. Household overcrowding during the first 1000 days was not known. We measured current household overcrowding as an estimate of conditions the study child may have experienced earlier in life. Current household overcrowding was calculated by the number of persons sleeping per room. A value $\geq 2.5$ denoted houseold overcrowding (CONEVAL, 2015).

\section{Ethical approval}

The project was approved by the Bioethics Committee for the Study of Human Beings of the Centre for Research and Advanced Studies of the National Polytechnic Institute (Cinvestav-IPN) and by the Ethical Advisory Committee of Loughborough University. Mothers who accepted taking part on the study had 
to signed informed consent forms. The chidren provided verbal consent from the before measurements started.

\section{Statistical analysis}

Multiple linear regression models were applied to each outcome: height $(\mathrm{cm})$, FMI $\left(\mathrm{kg} / \mathrm{m}^{2}\right)$ and FFMI $\left(\mathrm{kg} / \mathrm{m}^{2}\right)$. We log-transformed FMI and FFMI to achieve normal distribution. The main independent explanatory variables were birth weight $(\mathrm{kg})$, birth order ( $1^{\text {st }}$ reference, $2^{\text {nd }}, 3^{\text {rd }}$ or higher), duration of breastfeeding (months), and age at first food introduction (months). We also included maternal age and height as variables associated with birthweight and offspring's postnatal growth. Models were adjusted for maternal level of formal education (years) and household overcrowding (reference $=$ no), as proxies for household socioeconomic conditions. The FMI and FFMI models were adjusted by age (years) and sex (reference = boys). Model validity was confirmed when the residuals met the assumptions of normality. We used the variance inflation factor (VIF) to confirm absence of collinearity between predictors. We estimated the standardized coefficient (beta weights) to identify the most important explanatory factors in each model. Significance level was $\alpha=0.05$ in all models. Statistical analyses were completed with Stata/IC 11.1 for Windows (StataCorp LP 2009).

\section{RESULTS}

Basic descriptive statistics and a summary of children's nutritional status are shown in Table 1. The prevalence of stunting and OW/OB were slightly higher in boys, but girls showed a higher mean value of waist circumference or central adiposity; nevertheless, none of these sex differences were statistically significant.

Seventy-three percent of mothers had a stature below $150 \mathrm{~cm}$ (Table 2). Almost half of children were first-born, and most $(87.6 \%)$ had a birth weight within the normal range $(2,500-3,999 \mathrm{~g})$. Only $8 \%$ were low birth weight. The median breastfeeding duration was 8 months and $74.2 \%$ were breastfed for at least 6 months. Median age of introduction of solid foods was 6 months. Maternal schooling was low, since most of the mothers had only nine years of formal 
education $(72.7 \%)$. The majority $(68 \%)$ of the households were classified as overcrowded.

\section{TABLE 1 HERE}

\section{TABLE 2 HERE}

\section{Early life factors and child growth}

Results of the regression models for the three outcomes are showed in Table 3. Significant predictors for children's height were greater birth weight, being firstborn, and a younger age at first solid food introduction. Also older maternal age and greater maternal height were shown to have a positive influence on height at age 6-8 years. The model for FMI indicated that children have more fat if they had a higher birthweight and if their mother was older and taller. They tended to have less body fat if they were third-born (or subsequent). Finally, the FFMI model indicated that children's fat-free mass increased as their birthweight and maternal height increased. Beta weights (standardized coefficients) showed that maternal height was the most influential factor on children's height, while maternal age and birth weight were most influential for FMI and FFMI, respectively.

\section{TABLE 3 HERE}

\section{DISCUSSION}

The majority of children in this study (88\%) had a healthy birth weight, similar to that reported by Azcorra et al. (2016) for all births in Yucatan in 2013. However, during post-natal development, a high proportion of children exhibited stunting and overweight, the dual-burden condition that can lead them to compromised health later in life. The presence of stunting and overweight in these children suggest that some factors experienced in postnatal life are playing a role. These results agree with previous published studies (Bogin et al., 2014; Varela-Silva et al., 2009; Varela-Silva et al., 2012), but the previous research focused on the same sample addressed the effects of later childhood (i.e., post age 3 years 
old) environmental factors on growth (Azcorra et al., 2015a). Here we focused on the first 1000 days of growth and development.

The three regression models all suggest that birth weight positively influenced the three outcomes of interest (Table 3). Birth weight is a good indicator of uterine environmental quality and a good predictor of risk for neonatal morbidity and mortality. A healthy birth weight functions as a protective factor for linear growth when exposed to environmental stressors (Schell, 1998; Himes, 1998; Himes, 2004). The positive association between birth weight and height is well known (Datta Gupta et al., 2013; Ibáñez et al., 2000; Li et al., 2003; Opdahl et al., 2008). Prior work among Maya populations has shown that birth weight is positively related to future stature (Varela-Silva et al., 2009).

Our literature review shows positive associations between birth weight and overweight/obesity (Danielzik et al., 2004; Glavin et al., 2014; Panagiotakos et al., 2008). This needs to be approached with caution because these findings are based on body mass index (BMI) as a measure of adiposity. BMI generally increases with greater adiposity, but it is not possible to establish whether relationships with the $\mathrm{BMI}$ are primarily driven by fat or fat-free mass (Rogers, 2003). We found a positive association between FMI and birth weight, but our results also show a positive association between birth weight and FFMI, which agrees with results reported by Kulkarni et al. (2014) and Singhal et al. (2003). Furthermore, the standardized coefficients in FFMI model show that birth weight is the variable with higher influence over the outcome in this sample (Table 3).

In our models, the second and later-born children had lower height, while the third born children had a lower FMI compared to first-born. Similar results were reported by Savage et al. (2013a) in their study of a sample of 3 to 7-year-olds in New Zealand. In the light of these results, the seminal question is: What are the causes for first-born children to have a greater height than their later-born siblings, even if they had a lower birth weight? We attempted to explain this by looking for differences in early nutrition practices according to birth order, but we found no evidence for this. Parents of first-born children may be relatively inexperienced in infant care but have only one offspring requiring attention. This combination may drive them to invest more effort and resources into caretaking 
than they do with any subsequent children. In addition, for at least a certain period, first-born children do not have to share time, parental attention or any other resources with siblings. In a phenomenon known as the dilution hypothesis, the opposite occurs with second-born and later children (Becker and Tomes, 1976; Lundberg and Svaleryd, 2016). Nonetheless, the greater experience of parents with subsequent siblings may also function as a buffer against the lack of singular attention. Another important aspect to consider in future analysis is the elapsed period between births. This could let us know if the mother had enough time to recover the biological resources invested in the previous birth. The lack of data about intergenesic period in those children with an older sibling is a limitation of this study.

In addition to the dilution hypothesis other explanations could be in play. The presence of an older sibling may have negative effects on the growth of younger siblings due to psychosocial competition (Hermanussen and Scheffler, 2016). Sibling competition occurs even in families with good socioeconomic conditions in which there is no resource competition. The Avon Longitudinal Study of Parents and Children, a study of a sample in the UK, reported that with each additional older sibling, the studied child was up to $3 \mathrm{~cm}$ shorter by age ten (Lawson and Mace, 2008). Neither the economic conditions of the family nor the sex of the older sibling influenced this finding. These families were relatively wealthy, the children were well-fed, and all had universal health care and education, with extra benefits to those in need. Bogin (2016) proposed that sibling rivalry may have impacts on the hypothalamic-pituitary-adrenal (HPA) axis, cortisol reactivity, and GH/IGF-1 levels (Fey and Trillmich, 2008; Huchard et al., 2016), which can all impact growth and final size. Overall, the data on the association between birth order and child health is limited (Lundberg and Svaleryd, 2016). Differences in height and other sibling phenotypes seem to be best explained by a matrix of complexly interacting biocultural factors (Barclay, 2015).

The association between age at solid food introduction and obesity risk is not clear; we did not find any association in our regression models. We found a negative association with child height. Early food introduction (before 4 months of age) has been associated with a higher risk of gastrointestinal illness and 
infections that could lead to growth faltering (Huh et al., 2011; Kramer et al., 2003; Kuo et al., 2011), but, continued breastfeeding is a protective factor for infants who begin solid food consumption at an early age, an advantage not available to those who were never breastfed or stopped breastfeeding before 4 months of age (Huh et al., 2011). Our results do not fit with the previous published literature. This poses the question: What age is too early for food introduction, and what age is too late to allow maximum expression of growth?

Duration of breastfeeding was not associated with the outcome variables, but age at initial food introduction was an important event for later growth. Some studies maintain that effects of breastfeeding on child health are unclear (Colen and Ramey, 2014; Hediger et al., 2001). Evidence for an association between breastfeeding and obesity risk has been inconsistent (Rios-Castillo et al., 2015). Even though many studies suggest breastfeeding as a protective factor against obesity, those that include direct measurements of adiposity report no association (Gale et al., 2007). For example, Yan et al. (2014), Jarpa M. et al. (2015) and Bell et al. (2018) concluded that breastfeeding is a protective factor against obesity risk, but their outcome variables were BMI or weight-for-age which do not assess fatness directly. Discrepancies between studies could be attributed to differences in the parameters measured or to social patterns of breastfeeding (Ramirez-Silva et al., 2015). In the present study, the participants' socioeconomic levels were almost uniformly low, and all were Maya, an indigenous population that share a set of cultural patterns, including some related to infant care. For example, both grandmothers and aunts provide advice to the mother, based on their beliefs or experience. In many cases, this family advice is the main reason for stopping exclusive breastfeeding and starting to offer solid food before the $6^{\text {th }}$ month of life (Briceño Medina, 2017; Reyes Gutiérrez and Cervera Montejano, 2013). To understand the influence of age at initial food introduction requires further research, especially on the type of food initially offered to infants (Morgen et al., 2018).

Maternal age was shown to be associated with the three outcomes and was the most important factor explaining FMI in children according to the standardized coefficients in this sample. In previous research, this variable has been positively associated with offspring's growth status (Chandler-Laney et al., 
2013; Savage et al., 2013b). We suggest that older women have on average healthier offspring and this could be a result of social and economic benefits that accrue with age, rather than due to a direct effect of the mother's biological status. In some groups, birth of the first child is delayed as potential parents strive to attain better living conditions (Barclay and Myrskylä, 2016; Frejka and Sardon, 2006; Martínez et al., 2012; Mathews and Hamilton, 2009; Mathews and Hamilton, 2014). Older first-time mothers may therefore have achieved several conditions that contribute to a healthier and less stressful home environment for their children when compared to younger mothers. There is also some evidence that older women get more social support than younger women, and dote more on their children (Kim et al., 2017).

Maternal height was positively associated with child height and FMl, which agrees with reports that maternal somatic characteristics are associated with offspring growth (Addo et al., 2013; Ferreira et al., 2009). In addition, the standardized coefficients of our child height models revealed maternal height as the most important factor explaining FFMI. Varela-Silva et al. (2009) found that children of low stature mothers $(<150 \mathrm{~cm})$ had a greater risk of obesity than children of taller woman, but that study defined obesity using BMI. Using heightfor-age and weight-for-age, Machado Amorim et al. (2011) reported maternal height as one of the most important determinants of nutritional status of offspring in a cohort of 8-year olds Brazilian children.

Current overcrowding in the home was not associated with the outcomes, even though this variable is commonly reported as an important factor in child health, growth and development (Kuh and Wadsworth, 1989). Possible reasons for this result is that we did not asses overcrowding during the first 1000 days and we characterized overcrowding as a dichotomous variable (i.e. those who lived in overcrowded housing versus those who did not). It may be better to consider overcrowing as a continuous variable. Overcrowding during the 1000 days was not known.

Previous research reported that the main factors related to obesity in Mexican children and adolescents are exposure to the nutrition transition, sedentary lifestyles and children's patterns of physical activity, lack of leisure spaces, 
erroneous beliefs about health, socioeconomic limitations, low breastfeeding rates and quality of maternal diet (Aceves-Martins et al., 2016; Woo and Martin, 2015). Data from a representative sample of elementary school students in Merida supports these conclusions (Mendez Dominguez, 2013). In the present study we add early life factors associated to changes in fat mass in children: maternal age, maternal height, birth order and birth weight.

In conclusion, the explanatory variables we used in this study were restricted to factors during the first 1000 days of life and current home overcrowding. We found that children's birth weight was positively associated with children's height, FMI and FFMI. Birth order was negatively related with height, and FMI during childhood. An earlier age at solid food introduction was related with greater child height. In addition, greater maternal height and age seems to be associated with higher values in the outcome variables. Our findings suggest that factors experienced during early development have an influence on the presence of nutritional dual burden among Maya children in Yucatan.

\section{ACKNOWLEDGMENTS}

The authors thank Graciela Valentín and Adriana Vázquez-Vázquez for their assistance in the fieldwork. The research reported herein was partially funded by the Conacyt (Conacyt-Ciencia Básica, 168047) and master's fellowships granted to SSE (592613).

The authors declare no conflict of interest.

\section{AUTHOR CONTRIBUTIONS}

SSE and FD wrote the first draft of the manuscript. SSE and HA analyzed the data. HA, BB, AH, RS, and IVS, read, revised and added intellectual content the manuscript. BB, HA, and SSE, worked on the final version of the manuscript.

\section{REFERENCES}

Aceves-Martins, M., Llauradó, E., Tarro, L., Solà, R., \& Giralt, M. (2016).

Obesity promoting factors in Mexican children and adolescents: challenges and opportunities. Global Health Action, 9(1), 29625. 
Addo, O. Y., Stein, A. D., Fall, C. H., Gigante, D. P., Guntupalli, A. M., Horta, B. L., . . Martorell, R. (2013). Maternal height and child growth patterns. Journal of Pediatrics, 163(2), 549-554.

Azcorra, H., Dickinson, F., Bogin, B., Rodríguez, L., \& Varela-Silva, M. I. (2015). Intergenerational influences on the growth of Maya children: The effect of living conditions experienced by mothers and maternal grandmothers during their childhood. American Journal of Human Biology, 27(4), 494-500.

Azcorra, H., Rodríguez, L., Varela-Silva, M. I., Datta Banik, S., \& Dickinson, F. (2015). Intergenerational changes in knee height among Maya mothers and their adult daughters from Merida, Mexico. American Journal of Human Biology, 27(6), 792-797.

Azcorra, H., Valentín, G., Vázquez-Vázquez, A., \& Dickinson, F. (2010). Growth status in children and adolescents in Yucatan, Mexico: a human ecology perspective. Studies in Human Ecology. Hanoi: Publishing House for Science and Technology, 121-138.

Azcorra, H., Varela-Silva, M. I., Rodriguez, L., Bogin, B., \& Dickinson, F. (2013). Nutritional status of Maya children, their mothers, and their grandmothers residing in the City of Merida, Mexico: Revisiting the leg-length hypothesis. American Journal of Human Biology, 25(5), 659-665.

Azcorra, H., Vázquez-Vázquez, A., Mendez, N., Carlos Salazar, J., \& DattaBanik, S. (2016). Maternal maya ancestry and birth weight in Yucatan, Mexico. American Journal of Human Biology, 28(3), 436-439.

Barclay, K. (2015). Birth order and educational attainment: evidence from fully adopted sibling groups. Intelligence, 48, 134-143. 
Barclay, K., \& Myrskylä, M. (2016). Advanced maternal age and offspring outcomes: Reproductive aging and counterbalancing period trends. Population and Development Review, 42(1), 69-94.

Becker, G. S., \& Tomes, N. (1976). Child endowments and the quantity and quality of children. Journal of Political Economy, 84(4), S143-S162.

Bell, S., Yew, S., Devenish, G., Ha, D., Do, L., \& Scott, J. (2018). Duration of Breastfeeding, but Not Timing of Solid Food, Reduces the Risk of Overweight and Obesity in Children Aged 24 to 36 Months: Findings from an Australian Cohort Study. International Journal of Environmental Research and Public Health, 15(4), 599.

Bogin, B. (2001). The Growth of Humanity. New York: Wiley-Liss.

Bogin, B. (1999). Patterns of Human Growth, second edition. Cambridge University Press.

Bogin, B. (2016). Was there an evolutionary purpose to bullying? The Conversation. Retrieved July 25 2019, from https://theconversation.com/wasthere-an-evolutionary-purpose-to-bullying-70230.

Bogin, B., Azcorra, H., Wilson, H. J., Vázquez-Vázquez, A., Avila-Escalante, M. L., Castillo-Burguete, M. T., . . . Dickinson, F. (2014). Globalization and children's diets: The case of Maya of Mexico and Central America. Anthropological Review, 77(1), 11-32.

Bogin, B and MacVean, R.B. (1982). Ethnic and secular influences on the size of seven year old children living in Guatemala. American Journal of Physical Anthropology, 59: 393-398.

Bracamonte, P. (2007). Una Deuda Histórica: Ensayo sobre las condiciones de pobreza secular entre los mayas de Yucatán. México, DF: CIESAS-Porrúa-ICY. 
Briceño Medina, A. M. (2017). Factores selectos asociados a características de la lactancia materna en Mérida, México. Maestría en Ciencias en la especialidad de Ecología Humana, Centro de Investigación y de Estudios Avanzados del Instituto Politécnico Nacional, Mérida, México.

Colen, C. G., \& Ramey, D. M. (2014). Is breast truly best? Estimating the effects of breastfeeding on long-term child health and wellbeing in the United States using sibling comparisons. Social Science \& Medicine, 109, 55-65.

CONEVAL. (2015). Medición de la pobreza Retrieved May 25 2016, from http://www.coneval.org.mx/Medicion/Paginas/Medici\%C3\%B3n/Calidad-yespacios-en-la-vivienda.aspx

Chandler-Laney, P. C., Gower, B. A., \& Fields, D. A. (2013). Gestational and early life influences on infant body composition at 1 year. Obesity, 21(1), 144148.

Danielzik, S., Czerwinski-Mast, M., Langnäse, K., Dilba, B., \& Müller, M. J. (2004). Parental overweight, socioeconomic status and high birth weight are the major determinants of overweight and obesity in 5-7 y-old children: baseline data of the Kiel Obesity Prevention Study (KOPS). International Journal of Obesity and Related Metabolic Disorders, 28(11), 1494-1502.

Datta Gupta, N., Deding, M., \& Lausten, M. (2013). The effect of low birth weight in height, weight and behavioral outcomes in the medium-run. Economics and Human Biology, 11(1), 42-55.

Dickinson Bannack, F. H. (1997). Desnutrición y obesidad en poblaciones yucatecas. In Seminario Permanente de Antropología Urbana. Un modeo multidisciplinario en el estudio del fenómeno suburbano (Ed.), Significación Sociocultural de la Variación Morfológica (pp. 69-79). México.

Ferreira, H. S., Moura, F. A., Cabral Júnior, C. R., Florencio, T. M. M. T., Viera, R. C., \& de Assuncao, M. L. (2009). Short stature of mothers from an area 
endemic for undernutrition is associated with obesity, hypertension and stunted children: a population-based study in the semi-arid region of Alagoas, Northeast Brazil. British Journal of Nutrition, 101, 1239-1245.

Fey, K., \& Trillmich, F. (2008). Sibling competition in guinea pigs (Cavia aperea f. porcellus): scrambling for mother's teats is stressful. Behavioral Ecology and Sociobiology, 62, 321-329.

Frejka, T., \& Sardon, J.-P. (2006). First birth trends in developed countries: Persisting parenthood postponement. Demographic Research, 15(6), 147-180.

Frisancho AR. (2008). Anthropometric Standards: An Interactive Nutritional Reference of Body Size and Body Composition for Children and Adults. United States of America: The University of Michigan Press. 335 p.

Gale, C. R., Javaid, M. K., Robinson, S. M., Law, C. M., Godfrey, K. M., \& Cooper, C. (2007). Maternal size in pregnancy and body composition in children. Journal of Clinical Endocrinology and Metabolism, 92(10), 3904-3911.

Glavin, K., Roelants, M., Strand, B. H., Júlíusson, P. B., Lie, K. K., Helseth, S., \& Hovengen, R. (2014). Important periods of weight development in childhood: a population-based longitudinal study. BMC Public Health, 14(1), 160.

Gluckman , P. D., Hanson , M. A., Cooper , C., \& Thornburg , K. L. (2008). Effect of in utero and early-life conditions on adult health and disease. New England Journal of Medicine, 359(1), 61-73.

Hanson, M. A., \& Gluckman, P. D. (2014). Early developmental conditioning of later health and disease: physiology or pathophysiology? Physiological Reviews, 94(4), 1027-1076.

Hediger, M. L., Overpeck, M. D., Kuezmarski, R. J., \& Ruan, W. J. (2001). Association between infant breastfeeding and overweight in young children. JAMA, 285. 
Hermanussen, M., \& and Scheffler, C. (2016). Stature signals status: the association of stature, status and perceived dominance-a thought experiment. Anthropologischer Anzeiger, 73, 265-274.

Himes, J. H. (1998). Body-size at birth. In S. J. Ulijaszek, F. E. Johnston \& M. A. Preece (Eds.), The Cambridge Encyclopedia of Human Growth and Development (pp. 371-372). Cambridge, United Kingdom: Cambridge University Press.

Himes, J. H. (2004). Why study child growth and maturation? In R. C. Hauspie, N. Cameron \& L. Molinari (Eds.), Methods in Human Growth Research. Cambridge, United Kingdom: Cambridge University Press.

Huchard, E., English, S., Bell, M. B. V., Thavarajah, N., \& Clutton-Brock, T. (2016). Competitive growth in a cooperative mammal. Nature, 533, 532-534.

Huh, S. Y., Rifas-Shiman, S. L., Taveras, E. M., Oken, E., \& Gillman, M. W. (2011). Timing of solid food introduction and risk of obesity in preschool-aged children. Pediatrics, 127.

Ibáñez, L., Ferrer, A., Victoria Marcos, M., Rodríguez Hierro, F., \& de Zegher, F. (2000). Early puberty: rapid progression and reduced final height in girls with low birth weight. Pediatrics, 106(5).

INEGI. (2010). México en cifras. Información nacional, por entidad federativa y municipios Retrieved May 15 2018, from http://www.inegi.org.mx/

Jarpa M., C., Cerda L., J., Terrazas M., C., \& Cano C, Carmen. (2015). Lactancia materna como factor protector de sobrepeso y obesidad en preescolares. Revista Chilena de Pediatría, 86(1), 32-37.

Kim, T. H. M., Rotondi, M., Connolly, J., \& Tamim, H. (2017). Characteristics of social support among teenage, optimal age, and advanced age women in 
Canada: An analysis of the National Longitudinal Survey of Children and Youth. Maternal and Child Health Journal, 21(6), 1417-1427.

Kramer, M. S., Guo, T., Platt, R. W., Sevkovskaya, Z., Dzikovich, I., Collet, J.P., . . Bogdanovich, N. (2003). Infant growth and health outcomes associated with 3 compared with 6 mo of exclusive breastfeeding. American Journal of Clinical Nutrition, 78(2), 291-295.

Kulkarni, B., Hills, A. P., \& Byrne, N. M. (2014). Nutritional influences over the life course on lean body mass of individuals in developing countries. Nutrition Reviews, 72(3), 190-204.

Kuo, A. A., Inkelas, M., Slusser, W. M., Maidenberg, M., \& Halfon, N. (2011). Introduction of solid food to young infants. Maternal and Child Health Journal, 15(8), 1185-1194.

Kuzawa, C. W. (2005). Fetal origins of developmental plasticity: Are fetal cues reliable predictors of future nutritional environments? American Journal of Human Biology, 17(1), 5-21.

Lawson, D. W., \& Mace, R. (2008). Sibling configuration and childhood growth in contemporary British families. International Journal of Epidemiology, 37(6), 1408-1421.

Li H, Stein AD, Barnhart HX, Ramakrishman U, Martorell R. (2003). Associations between prenatal and postnatal growth and adult body size and composition. American Journal of Clinical Nutrition 77:1498-1505.

Lohman, T. G., Roche, A. F., \& Martorell, R. (1988). Anthropometric Standardization Reference Manual. Champaign, IL: Human Kinetics.

Lundberg, E., \& Svaleryd, H. (2016). Birth order and child health. Labour Market and Discrimation Studies. Linnaeus University. Växjö, Suecia. 
Machado Amorim, R. d. J., de Carvalho Lima, M., Cabral de Lira, P. I., \& Emond, A. M. (2011). Does low birthweight influence the nutritional status of children at school age? A cohort study in northeast Brazil. Maternal \& Child Nutrition, 7(3), 295-306.

Martínez, G., Daniels, K., \& Chandra, A. (2012). Fertility of men and women aged 15-44 years in the United States: National Survey of Family Growth, 20062010 (U. S. D. O. H. H. SERVICES, Trans.) National Health Statistics Report (pp. 29). Hyattsville: Centers for Disease Control and Prevention National Center for Health Statistics.

Martorell, R., \& Zongrone, A. (2012). Intergenerational Influences on Child Growth and Undernutrition. Paediatric and Perinatal Epidemiology, 26, 302-314.

Mathews, T. J., \& Hamilton, B. E. (2009). Delayed childbearing: More women are having their first child later in life (U. S. D. O. H. A. H. SERVICES, Trans.) NCHS Data Brief (pp. 8). Hyattsville: Centers for Disease Control and Prevention National Center for Health Statistics.

Mathews, T. J., \& Hamilton, B. E. (2014). First births to older women continue to rise NCHS Data Brief (pp. 8). Hyattsville: National Center for Health Statistics.

Mendez Dominguez, N. (2013). Aspectos del ambiente familiar y escolar relativos a los hábitos de alimentación y actividad física que se asocian al exceso de peso entre escolares de Mérida Yucatán. Doctorado, Universidad Autónoma de Yucatán, Mérida, México.

Mendez, N., Barrera-Pérez, T. L. M., Palma-Solis, M., Zavala-Castro, J., Dickinson, F., Azcorra, H., \& Prelip, M. (2016). Ethnicity and income impact on $\mathrm{BMI}$ and stature of school children living in urban southern Mexico. Journal of Biosocial Science, 48(02), 143-157. 
Morgen, C. S., Ängquist, L., Baker, J. L., Andersen, A.-M. N., Sørensen, T. I. A., \& Michaelsen, K. F. (2018). Breastfeeding and complementary feeding in relation to body mass index and overweight at ages 7 and $11 \mathrm{y}$ : a path analysis within the Danish National Birth Cohort. The American Journal of Clinical Nutrition, 107(3), 313-322.

H. Ayuntamiento de Motul. Motul. Enciclopedia de los Municipios y

Delegaciones de México. Retrieved August 8 2019, from

http://www.inafed.gob.mx/work/enciclopedia/EMM31yucatan/municipios/31052a html

OMS. (2015). Lactancia materna Retrieved October 26 2015, 2015, from http://www.who.int/topics/breastfeeding/es/

Opdahl, S., Nilsen, T. I. L., Romundstad, P. R., Vanky, E., Carlsen, S. M., \& Vatten, L. J. (2008). Association of size at birth with adolescent hormone levels, body size and age at menarche: relevance for breast cancer risk. British Journal of Cancer, 99(1), 201-206.

Panagiotakos, D. B., Papadimitriou, A., Anthracopoulos, M. B., Konstantinidou, M., Antonogeorgos, G., Fretzayas, A., \& Priftis, K. N. (2008). Birthweight, breast-feeding, parental weight and prevalence of obesity in schoolchildren aged 10-12 years, in Greece; the Physical Activity, Nutrition and Allergies in Children Examined in Athens (PANACEA) study. Pediatrics International, 50(4), 563-568.

Ramirez, E., Valencia, M. E., Bourges, H., Espinosa, T., Moya-Camarena, S. Y., Salazar, G., Aleman-Mateo, H. (2012). Body composition prediction equations based on deuterium oxide dilution method in Mexican children: a national study. European Journal of Clinical Nutrition, 66(10):1099-1103.

Ramirez-Silva, I., Rivera, J. A., Trejo-Valdivia, B., Martorell, R., Stein, A. D., Romieu, I., ... Ramakrishnan, U. (2015). Breastfeeding status at age 3 months 
is associated with adiposity and cardiometabolic markers at age 4 years in Mexican children. Journal of Nutrition, 145(6), 1295-1302.

Relethford, J. (1995). The use of surnames in the study of human variation and plasticity. In B. B. Mascie-Taylor C (Ed.), Human variability and plasticity (pp. 146-158). Cambridge, UK:: Cambridge University Press.

Reyes Gutiérrez, G. Y., \& Cervera Montejano, M. D. (2013). Etnoteorías y prácticas de lactancia materna en una comunidad maya de Yucatán. Estudios de Antropología Biológica, XVI, 907-928.

Rios-Castillo, I., Cerezo, S., Corvalán, C., Martínez, M., \& Kain, J. (2015). Risk factors during the prenatal period and the first year of life associated with overweight in 7-year-old low-income Chilean children. Maternal \& Child Nutrition, 11(4), 595-605.

Rogers, I. (2003). The influence of birthweight and intrauterine environment on adiposity and fat distribution in later life. International Journal of Obesity, 27, 755-777.

Savage, T., Derraik, J. G. B., Miles, H. L., Mouat, F., Cutfield, W. S., \& Hofman, P. L. (2013a). Birth order progressively affects childhood height. Clinical Endocrinology, 79(3), 379-385.

Savage, T., Derraik, J. G. B., Miles, H. L., Mouat, F., Hofman, P. L., \& Cutfield, W. S. (2013b). Increasing maternal age is associated with taller stature and reduced abdominal fat in their children. Plos One, 8(3).

Sayers, S., Singh, G., Mott, S., McDonnell, J., \& Hoy, W. (2009). Relationships between birthweight and biomarkers of chronic disease in childhood: Aboriginal Birth Cohort Study 1987-2001. Paediatric and Perinatal Epidemiology, 23(6), 548-556. 
Schell, L. M. (1998). Environmental factors influencing birth-weight. In S. J. Ulijaszek, F. E. Johnston \& M. A. Preece (Eds.), The Cambridge Encyclopedia of Human Growth and Development. Cambridge, Unitek Kingdom: Cambridge University Press.

Singhal, A., Wells, J., Cole, T. J., Fewtrell, M., \& Lucas, A. (2003). Programming of lean body mass: a link between birth weight, obesity, and cardiovascular disease? American Journal of Clinical Nutrition, 77(3), 726-730.

Stinson, S. (2012). Growth variation: biological and cultural factors. In S. Stinson, B. Bogin \& D. O'Rourke (Eds.), Human Biology: an Evolutionary and Biocultural Perspective ( ${ }^{\circ}$ ed., pp. 587-635). New Jersey: John Wiley \& Sons, Inc.

Varela-Silva, M. I., Azcorra, H., Dickinson, F., Bogin, B., \& Frisancho, A. R. (2009). Influence of maternal stature, pregnancy age, and infant birth weight on growth during childhood in Yucatan, Mexico: A test of the intergenerational effects hypothesis. American Journal of Human Biology, 21(5), 657-663.

Varela-Silva, M. I., Dickinson, F., Wilson, H., Azcorra, H., Griffiths, P. L., \& Bogin, B. (2012). The nutritional dual-burden in developing countries - how is assessed and what are the health implications? Collegium Antropologicum, 36(1), 39-45.

Wells, J. C. (2013). Commentary: The thrifty phenotype and the hierarchical preservation of tissues under stress. International Journal of Epidemiology, 42(5), 1223-1227.

Wells, J. C. K. (2009). Historical cohort studies and the early origins of disease hypothesis: making sense of the evidence. Proceedings of the Nutrition Society, $68,179-188$.

Wells, J. C. K. (2014). Adaptive variability in the duration of critical windows of plasticity. Evolution, Medicine, and Public Health, 109-121. 
WHO. 2014. Chapter 2. Stunted growth: what actually causes it? Childhood stunting: Context, causes and consequences

https://www.who.int/nutrition/healthygrowthproj_stunted_videos/en/.p 00:07:12.

Woo, J. G., \& Martin, L. J. (2015). Does Breastfeeding Protect Against

Childhood Obesity? Moving Beyond Observational Evidence. Current Obesity Reports, 4(2), 207-216.

Yan, J., Liu, L., Zhu, Y., Huang, G., \& Wang, P. P. (2014). The association between breastfeeding and childhood obesity: a meta-analysis. BMC Public Health, 14(1), 1267. 


\section{TABLES}

Table 1. Child growth status

\begin{tabular}{lcrrrr}
\hline & & Stunting & OW/OB & \multicolumn{2}{c}{ Central adiposity excess } \\
\hline Total & $\mathrm{n}$ & & $\begin{array}{c}\text { Waist } \\
\text { circumference }\end{array}$ & $\begin{array}{c}\text { Subscapular } \\
\text { skinfold }\end{array}$ \\
Boys & 260 & $11.9 \%$ & $36.5 \%$ & $32.3 \%$ & $29.0 \%$ \\
Girls & 132 & $13.6 \%$ & $39.4 \%$ & $28.8 \%$ & $21.2 \%$ \\
\hline
\end{tabular}

Stunting $<5^{\circ}$ percentile; OW/OB (overweight/obesity) $>85^{\circ}$ percentile; waist circumference $>85^{\circ}$ percentile; subscapular skinfold $>85^{\circ}$ percentile. 
Table 2. Descriptive statistics of early life factors

\begin{tabular}{lrrrr}
\hline & $\mathrm{n}$ & Median & Min & \multicolumn{1}{c}{ Max } \\
\hline Maternal age (years) & 260 & 24.9 & 15 & 43 \\
Maternal height (cm) & 260 & 147.8 & 132.5 & 163.3 \\
Birth order & 260 & 2 & 1 & 6 \\
Birth weight (g) & 258 & 3200 & 1200 & 4300 \\
Duration of breastfeeding (months) & 259 & 8 & 0 & 72 \\
Age at initial food introduction (months) & 259 & 6 & 2 & 24 \\
Maternal schooling (years) & 260 & 9 & 0 & 19 \\
Household overcrowding (index) & 258 & 2.5 & 1 & 10 \\
\hline
\end{tabular}

SD: Standard deviation. 
Table 3. Regression models for height, fat mass index and fat-free mass index, and childhood growth parameters

\begin{tabular}{|c|c|c|c|c|c|}
\hline Variables & Coefficient & $\mathrm{p}$ & \multicolumn{2}{|c|}{$\mathrm{Cl}(95 \%)$} & B \\
\hline \multicolumn{6}{|l|}{ Height } \\
\hline Maternal age (years) & 0.026 & 0.022 & 0.004 & 0.049 & 0.161 \\
\hline Maternal height $(\mathrm{cm})$ & 0.069 & 0.000 & 0.048 & 0.089 & 0.391 \\
\hline Birth order $2^{\text {nd }}$ & -0.273 & 0.025 & -0.512 & -0.034 & -0.144 \\
\hline $3^{\text {rd }}$ & -0.239 & 0.122 & -0.542 & 0.064 & -0.113 \\
\hline Birth weight $(\mathrm{kg})$ & 0.216 & 0.038 & 0.012 & 0.420 & 0.124 \\
\hline Duration of breastfeeding (months) & 0.004 & 0.399 & -0.005 & 0.013 & 0.051 \\
\hline Age at initial food introduction (months) & -0.045 & 0.030 & -0.086 & -0.005 & -0.128 \\
\hline Maternal education level (years) & -0.036 & 0.030 & -0.068 & -0.003 & -0.131 \\
\hline Overcrowding & -0.154 & 0.161 & -0.369 & 0.062 & 0.088 \\
\hline Constant & -11.318 & 0.000 & -14.56 & -8.078 & \\
\hline \multicolumn{6}{|l|}{ Fat mass index } \\
\hline Maternal age (years) & 0.013 & 0.003 & 0.005 & 0.022 & 0.216 \\
\hline Maternal height $(\mathrm{cm})$ & 0.009 & 0.026 & 0.001 & 0.018 & 0.140 \\
\hline Birth order $2^{\text {nd }}$ & -0.078 & 0.108 & -0.173 & 0.017 & -0.107 \\
\hline $3^{\text {rd }}$ & -0.037 & 0.026 & -0.256 & -0.017 & -0.170 \\
\hline Birth weight $(\mathrm{kg})$ & 0.112 & 0.006 & 0.032 & 0.192 & 0.168 \\
\hline Duration of breastfeeding (months) & -0.001 & 0.514 & -0.005 & 0.002 & -0.041 \\
\hline Age at initial food introduction (months) & -0.012 & 0.130 & -0.028 & 0.004 & -0.092 \\
\hline Maternal education level (years) & -0.008 & 0.175 & -0.021 & 0.004 & -0.084 \\
\hline Overcrowding & -0.054 & 0.215 & -0.139 & 0.031 & -0.081 \\
\hline Constant & -0.702 & 0.239 & -2.117 & 0.531 & \\
\hline \multicolumn{6}{|l|}{ Fat-free mass index } \\
\hline Maternal age (years) & 0.003 & 0.027 & 0.0004 & 0.006 & 0.161 \\
\hline Maternal height $(\mathrm{cm})$ & 0.002 & 0.126 & -0.0006 & 0.005 & 0.096 \\
\hline Birth order $2^{\text {nd }}$ & -0.005 & 0.747 & -0.036 & 0.026 & -0.022 \\
\hline $3^{\text {rd }}$ & -0.039 & 0.052 & -0.078 & 0.003 & -0.148 \\
\hline Birth weight $(\mathrm{kg})$ & 0.043 & 0.001 & 0.017 & 0.069 & 0.197 \\
\hline Duration of breastfeeding (months) & 0.0006 & 0.292 & -0.0005 & 0.002 & 0.066 \\
\hline Age at initial food introduction (months) & -0.001 & 0.632 & -0.007 & 0.004 & -0.029 \\
\hline Maternal education level (years) & $-8.49 e-06$ & 0.992 & -0.004 & 0.004 & -0.000 \\
\hline Overcrowding & -0.006 & 0.658 & -0.034 & 0.021 & -0.029 \\
\hline Constant & 1.880 & 0.000 & 1.446 & 2.314 & \\
\hline
\end{tabular}

Cl: confidence interval; B: beta coefficient. 